\title{
Butterfly diversity in tropical moist deciduous sal forests of Ankua Reserve Forest, Koina Range, Saranda Division, West Singhbhum District, Jharkhand, India
}

\author{
Arun P. Singh \\ Entomology Division, P.O. New Forest, Forest Research Institute (ICFRE), Dehradun, Uttarakhand 248006, India \\ Email: ranoteaps@gmail.com
}

Date of publication (online): 26 August 2010 Date of publication (print): 26 August 2010 ISSN 0974-7907 (online) | 0974-7893 (print)

Editor: Peter Smetacek

\section{Manuscript details:}

Ms \# 02274

Received 30 July 2009

Final received 11 March 2010

Finally accepted 23 July 2010

Citation: Singh, A.P. (2010). Butterfly diversity in tropical moist deciduous sal forests of Ankua Reserve Forest, Koina Range, Saranda Division, West Singhbhum District, Jharkhand, India. Journal of Threatened Taxa 2(9): 11301139

Copyright: () Arun P. Singh 2010. Creative Commons Attribution 3.0 Unported License. JoTT allows unrestricted use of this article in any medium for non-profit purposes, reproduction and distribution by providing adequate credit to the authors and the source of publication.

Author Details: ARUN P. SINGH works on the conservation of biodiversity of the Himalaya with special reference to butterflies and birds since past 18 years. His research work include ecology, taxonomy, environmental impact assessment (EIA) studies, along with teaching (Entomology and Wildlife Management) at Forest Research Institute University and Wildlife Institute of India at Dehradun. Presently, he heads the Ecology and Biodiversity Conservation Division, Rain Forest Research Institute (ICFRE), Jorhat, Assam.

Acknowledgements: This study was part of an EIA project of Indian Council of Forestry Research and Education (ICFRE). The author is thankful to DG (ICFRE), DDG (Extension, ICFRE) \& ADG and Sudhir Kumar, project manager (EIA Division, ICFRE), and Director, $\mathrm{FRI}$, for providing the necessary facilities to carry out this study.


OPEN ACCESS | FREE DOWNLOAD
Abstract: Butterflies were sampled during February and September 2008 using pollard walk method to assess the species diversity in the tropical moist deciduous sal forest habitats of Ankua Reserve Forest, Koina Range, Saranda Division, West Singhbhum District, Jharkhand. This area, a total of 999.9 ha, is being proposed for lease under an iron ore mining project. This short-term study revealed high beta diversity of butterflies in these forest tracts, with 71 species recorded. Of these, two species, Leopard Lacewing Cethosia cyane (Drury, 1773) and Restricted Demon Notocrypta curvifascia (C. \& R. Felder, 1862), are new records for Jharkhand state while three other species recorded are listed in the Indian Wildlife (Protection) Act 1972. This study provides support for long-term conservation of these fragmented sal forest tracts to ensure biodiversity protection.

Keywords: Beta diversity, Central India, evenness, Indian Wildlife (Protection) Act 1972, similarity index, species diversity, threatened species.

\section{INTRODUCTION}

The Sal Shorea robusta forests of the Saranda Forest Division are rich in high and medium grade hematite deposits and many mines are operational in the area for extraction of iron ore. Recently, some new lease areas for iron ore extraction/mining inside sal forest tracts have been proposed and marked for private companies. As such these forest tracts are now threatened with mining and so is their biodiversity. A study was carried out in the sal forests of Ankua Reserve Forest in order to assess the status of fauna. The aim of the present study was to evaluate species diversity of butterflies and to identify species of conservation priority, if any, as there is no previous record of butterflies from West Singhbhum District, Jharkhand. In addition, understanding the biodiversity profile of the area can provide data for better mining practices, mitigation plans, and suggesting biodiversity offsets for the conservation of threatened biodiversity (ten Kate et al. 2004).

There are no previous records on butterflies in Saranda Division, West Singhbhum District, Jharkhand (Sinha1962; DFE 2009). Previous butterfly records from Jharkhand State pertain only to Hazaribagh and Ranchi districts (Morrison-Godfrey 1950) where 121 species (134 sub-species) were recorded. These records also included some areas of Manbhum District (a district in the erstwhile British 'East India', now known as 'Purulia District' in West Bengal). Recently, a checklist of 39 species was published for Dalma Wildlife Sanctuary, Jamshedpur District (Verma 2009). Also, a checklist of 174 species of butterflies is available from the adjoining states of Madhya Pradesh and Chattisgarh (Chandra et al. 2007).

Mining activity can be a potential threat to biodiversity in this area. Several studies have suggested that butterflies are key taxa for biodiversity monitoring because they reflected changes in land use patterns (Kunte 1997, 2000; Kunte et al. 1999; Kocker \& Williams 2000; Padhye et al. 2006). Butterflies are widely recognized as potentially valuable ecological indicators (Erhardt 
1855; Brown 1991; Kremen 1992) as they are sensitive to and directly affected by any alteration to their habitats, atmosphere, local weather and climate (Watt et al. 1968; Heath1981; Rosenberg et al. 1986; Dennis 1993). They are highly sensitive to changes in temperature, humidity, and light levels that are typically affected by habitat disturbance (Ehrlich et al. 1972; Blau 1980; Spitzer 1997; Brunzel \& Elligsen 1999; Balmer \& Erhardt 2000). In addition, butterfly diversity may serve as a surrogate for plant diversity because butterflies are directly dependant on plants, often in highly co-evolved situations (Ehrlich \& Raven 1964).

\section{Study area}

Ankua-Hatnaburu area (Image 1) of West Singhbhum District, Jharkhand is located about $20 \mathrm{~km}$ to the south of Manoharpur Town. It is about $60 \mathrm{~km}$ north-east from the district headquarters, Chaibasa, and lies

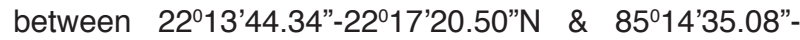
$85^{\circ} 17^{\prime} 16.66$ ' $\mathrm{E}$. The highest altitude in the area is $677 \mathrm{~m}$ and the lowest is $320 \mathrm{~m}$. Phyllites form the dominant rock types of the area. The soil colour varies from grey, greenish-grey, brown to reddish-brown. The Koina and the Karo rivers flow northward and, along with a series of NW-SE flowing tributaries, form the region's drainage system, finally joining the Mahanadi River. The area has a humid tropical climate. In summer temperature varies between $40-46{ }^{\circ} \mathrm{C}$ while winter temperatures get as cold as $4^{\circ} \mathrm{C}$. The area receives maximum rainfall during the South West Monsoon (July - September), which ranges between 1500 and $1700 \mathrm{~mm}$.

Based on Champion and Seth's classification (Champion \& Seth 1968; Department of Forest and Environment 2009), the forests of the Saranda Division of West Singhbhum District of Jharkhand have been categorized into five broad types, namely, northern dry mixed deciduous forests $5 \mathrm{~B} / \mathrm{C}_{2}$, dry peninsular sal forests$5 \mathrm{~B} / \mathrm{C}_{1 \mathrm{e}}$, moist peninsular sal forest $3 \mathrm{C} / \mathrm{C}_{2 \mathrm{e}}$, moist mixed deciduous forests $3 C / C_{3 a}$, northern tropical wet evergreen or semi-evergreen forests $\mathrm{iB} / 2 \mathrm{~B}$. The forests of Saranda Division are main tropophilous type (neither damp nor very dry) dominated by sal as the climatic climax. These forests are known as the home of sal due to prevalence of optimal climatic conditions for better germination, establishment, and development. Important tree species associated with sal in these forests are Anogeissus latifolia, Bauhinia semla, B. vahlii, Bombax ceiba, Careya arborea, Casearia elliptica, C. graveolens, Cassia fistula, Catunaregam spinosa, Dalbergia latifolia, Diospyros exculpta, D. melanoxylon, D, montana, Ehretia laevis, Garuga pinnata, Grewia tiliaefolia, Haldina cordifolia, Hymenodictyon orixense, Kydia calycina, Macaranga peltata, Miliusa velutina, Mitragyna parvifolia, Nyctanthes arbor-tristis, Pterocarpus marsupium, Schleichera oleosa, Spondias pinnata, Symplocos cochinchinensis, Syzygium cumini, Terminalia alata, T. bellirica, Trichilia connaroides and Ziziphus rugosa.

\section{METHODS}

\section{Sampling}

Four sites were selected in the proposed iron ore mine lease forest area (999.9ha), between coordinates

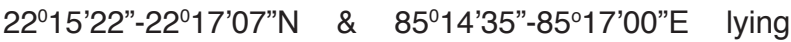
between 626-677 m, namely:

- Site-I (near Sukri-Dhobil Junction /Chiria bypass)Dense, high and mixed moist deciduous sal forest, under growth dense, no visible signs of grazing/ browsing by cattle.

- Site-Il (near Sukri mines) - Mixed sal forest with small openings and grassy patches, undergrowth thin due to grazing by cattle in some patches.

- Site-III (near Hathnaburu/Dhobil mines) -Sal forest edge close to operational Dobil mines with small-sized trees and openings with thin undergrowth due to grazing

- Site-IV (near Sukri-Dhobil road)- Dense, high and mixed sal forest but undergrowth thin due to grazing in some patches.

A two-day reconnaissance survey was carried out during February 2008 to identify the study sites. A random sampling was then conducted as a comprehensive survey was not possible due to time limitations, and restricted movement due to Naxalite insurgent activity in the study area. However, during September 2008, a four-day site specific sampling survey was possible in each of the four sites, but then heavy rains and major landslides restricted the movement through forest roads, reducing the number of working hours in the field.

During the September 2008 survey, a linear transect of $1 \mathrm{~km}$ each was chosen at each site for sampling. Each transect was trekked for $1.5 \mathrm{~h}$ to sample butterflies using the standard 'Pollard Walk' methodology. All the species encountered and their relative abundance were recorded daily while trekking along the foot trails. Voucher specimens were collected of some of the species that could not be identified in the field and some species were photographed. Specimens of some species were caught for identification and later released. Temperature during the September sampling period (23-26 September 2008; between 1000 and $1300 \mathrm{hr}$ ) varied between 25 and $28^{\circ} \mathrm{C}$ and relative humidity between 85 and $90 \%$.

\section{Statistical Analysis}

A. Shannon index - $\boldsymbol{H}^{\prime}$ : Species diversity was calculated using the Shannon Index, which combines the number of species within a site with the relative abundance of each species (Shannon 1948; Magurran 1988, Odum 1997; Krebs 1989).

$$
H^{\prime}=-\Sigma \text { pi In pi }
$$

Here, pi is the proportion of the ith species in the 


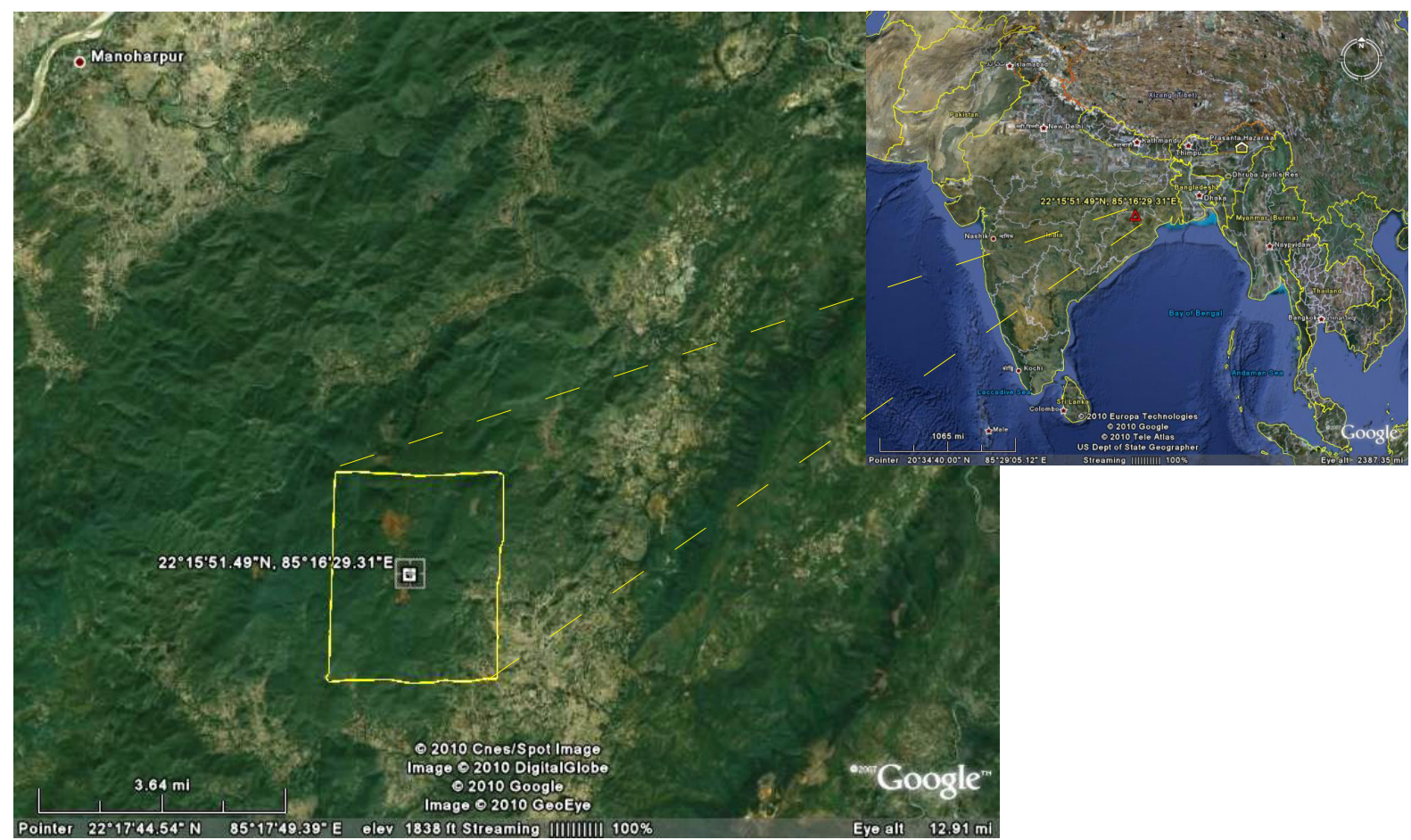

Image 1. Location of the study area

total sample. The number of species (species richness) in the community and their evenness in abundance (or equitability) are the two parameters that define $H^{\prime}$.

B. Pielou's Evenness index (Equitability) or J': The species evenness is the relative abundance or proportion of individuals among the species. Evenness of species reveals how their relative abundance is distributed in a particular sample or site (Pielou 1969; Magurran 1988).

$$
J^{\prime}=H^{\prime} / \ln \mathrm{S}
$$

Here, $\mathrm{S}$ is the number of species present in the site. The value of $J$ 'ranges from 0 to 1 . The less variation in communities between the species, the higher the value of $J$ '.

\section{Sørensen's Similarity Index:}

$$
B=2 c /\left(S_{1}+S_{2}\right)
$$

where, $S_{1}=$ the total number of species recorded in the first community, $S_{2}=$ the total number of species recorded in the second community, and $\mathrm{c}=$ the number of species common to both communities. The Sørensen's index (Sørensen 1948) is a very simple measure of beta diversity, ranging from a value of 0 where there is no species overlap between the communities, to a value of 1 when exactly the same species are found in both communities.

Identification of butterflies was done using the following literature: Evans (1932), Talbot (1939, 1947), WynterBlyth (1957), D'Abrera (1982, 1985, 1986), Haribal (1992) and Kunte (2000). The classification of butterflies followed here is based on Ackery (1984).

\section{RESULTS}

The study revealed the presence of 71 species of butterflies belonging to five families and 56 genera from all four sites during both sampling surveys (Appendix 1). An additional species, Gram Blue, Euchrysops cnejus was recorded in Ankua Reserve Forest but outside the study area. The total number of species recorded was lower during February (38) as compared to September (56). The most common species sampled during the study was the Common Grass Yellow Eurema hecabe (Image 2) which constituted $42.4 \%$ followed by Large Oak Blue Arhopala amantes (10.8\%) (Image 3), Common Sailer Neptis hylas (3.8\%) (Image 4), Chocolate Pansy Precis iphita (3.6\%), Grey Count Tanaecia lepidea (2.6\%) (Image 5), Common Emigrant Catopsilia crocale (2.2\%), Blue Mormon Papilio polymnestor (2.2\%) (Image 6), and Common Mormon Papilio polytes (2.2\%) of the total butterfly abundance in the study area (Appendix 1). The remaining 63 species had less than $2 \%$ abundance, individually, of the total abundance in the study area. Some species showed preference for particular sites. These were the Blue Mormon Papilio polymnestor and Colour Sergeant Athyma nefte (Image 7), which occurred only in sal forest site I with dense undergrowth and canopy, while Staff Sergeant Athyma selenophora (Image 8), Baronet Symphaedra nais (Image 9), Chestnut Rajah Charaxes sp.; Gaudy Baron Euthalia lubentina, and Grey Count Tanaecia lepidea preferred site III located at the sal forest edge. 


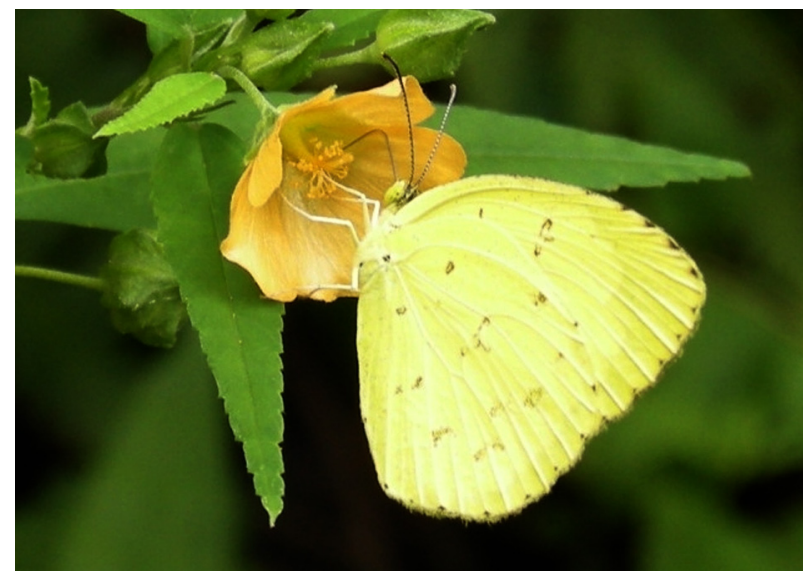

Image 2. Common Grass Yellow Eurema hecabe



Image 3. Large Oak Blue Arhopala amantes

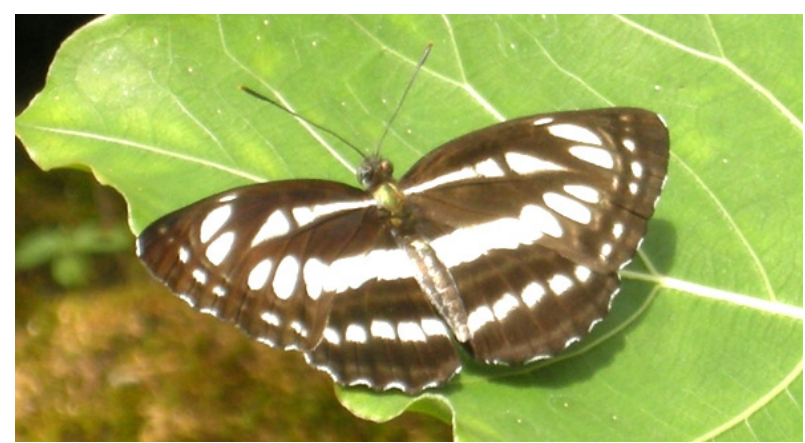

Image 4. Common Sailer Neptis hylas

The record of two species, the Leopard Lacewing Cethosia cyane (Drury, 1773) and the Restricted Demon Notocrypta curvifascia (C. \& R. Felder, 1862) in Ankua Forest Division, West Singhbhum District, are new for Jharkhand State and also for the region as they have not been mentioned in regional checklists (MorrisonGodfrey 1950; Chandra et al. 2007; Verma 2009).

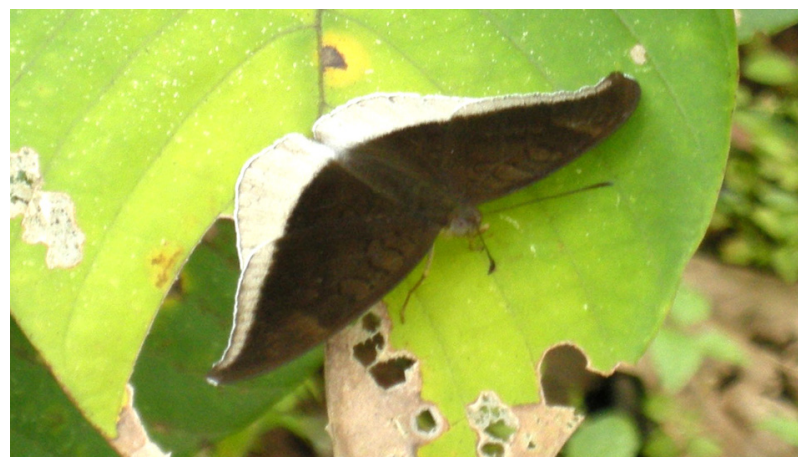

Image 5. Grey Count Tanaecia lepidea - male



Image 6. Blue Mormon Papilio polymnestor

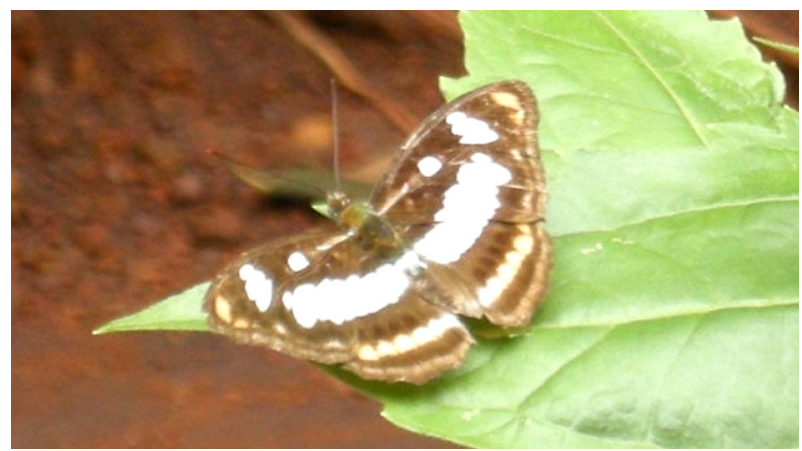

Image 7. Colour Sergeant Athyma nefte

\section{Species Accumulation Curve}

During the September 2008 sampling survey the species accumulation curve (Fig. 1) for the four sites sampled individually,over four successive days, increased from first to the fourth sampling though the number of new species added slowly decreased towards the end. However, addition of new species during each sampling in different sites suggested high beta diversity in the area and there was still scope for new species to be added 


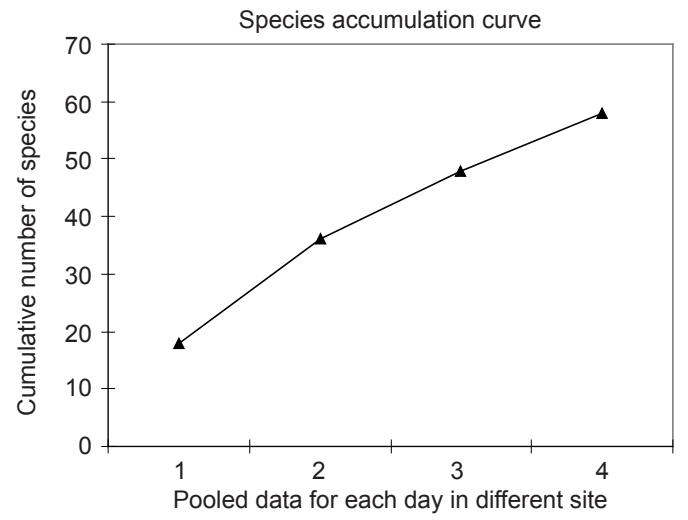

Figure 1. Species accumulation curve of butterflies in the four sites (1388.5ha area) sampled (1.5h each) over four successive days (23-26 September 2008) in sal forest habitats of Ankua Reserve Forest, Koina Range, Saranda Division, West Singhbhum District, Jharkhand.

Table 1. Similarity between four sites studied in terms of butterfly species composition (September 2008).

\begin{tabular}{|c|c|}
\hline Sites & Sorensen's Similarity Index \\
\hline I \& II & 0.2439 \\
\hline I \& III & 0.3830 \\
\hline I \& IV & 0.1661 \\
\hline II \& III & 0.2500 \\
\hline II \& IV & 0.1707 \\
\hline III \& IV & 0.2128 \\
\hline
\end{tabular}

after the last sampling.

\section{Species Diversity and Evenness of sites}

Species richness i.e. the total number of species encountered, diversity index, and evenness index did not vary much amongst the sites 1, 2 and 4 (Fig. 2). However, Site III had the highest value for all three of these parameters. The high value of the Shannon diversity index was mainly attributed to 'edge effect', as this forest site with an intermediate level of disturbance was located between a dense mixed sal forest and an already active open cast mining site.

\section{Similarity of sites for butterfly species}

Sørensen's Similarity index of all the four sites for butterfly species composition during September 2008 had values below 0.3830 (Table 1). The low value of this index is an indicator of high beta diversity in this forest area which suggests that all four sites hold a unique diversity of butterflies.

The Sørensen's similarity index between the two seasons (February and September) studied was 0.5053 which suggests seasonal change in species composition/ diversity of butterflies in the study area.

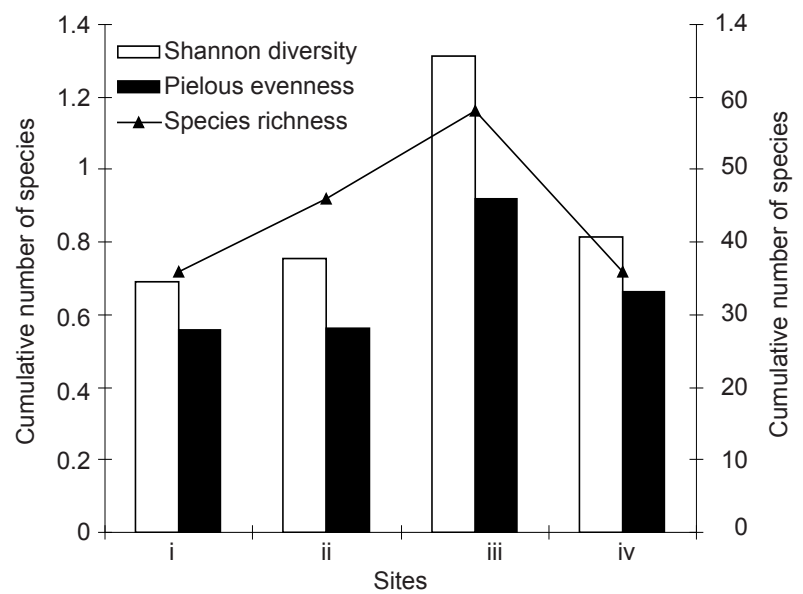

Figure 2. Relative species diversity, evenness, and richness of butterflies in the four sites sampled (1.5h each) in sal forest habitat of Ankua Reserve Forest Division, Koina Range, Saranda Division, West Singhbhum District, Jharkhand (23 -26 September 2008).

\section{DISCUSSION}

The present study was the first time that butterflies were evaluated in the sal forests of Saranda Divison, West Singhbhum District, Jharkhand. Results indicate high beta diversity of butterflies in these sal forest habitats. Seventyone species of butterflies were sampled in the study area, however these consist of mostly 'common' and 'generalist' species, as none of the species is threatened globally per the IUCN Red List 2008 and none is of 'rare' occurrence in India but are widely distributed (Wynter-Blyth 1957). Three species - Indigo Flash Rapala varuna, Gaudy Baron Euthalia lubentina, Pea Blue Lampides boeticus, sampled are protected by law as they are listed in the Indian Wildlife (Protection) Act 1972 under Schedule II, part II (Anonymous 2006). A specimen of Charaxes was also observed but it was not possible to either photograph it or capture it. Therefore, it is not possible to state with certainty whether it was Charaxes psaphon or Charaxes bernardus. Further surveys are required to clarify this point, which is of relevance, since the north-west Himalayan subspecies of Charaxes bernardus is listed in Schedule II, Part II of the Indian Wildlife (Protection) Act 1972.

Apart from butterflies, other threatened wildlife recorded in the study area during the present survey were, Asiatic Elephant Elephas maximus (Endangered; Choudhury et al. 2008); Sloth Bear Melursus ursinus (Vulnerable; Garshelis et al. 2008) and Indian Giant Squirrel Ratufa indica (Least Concern; Rajamani et al. 2009). Races of two species of birds, Green-billed Malkoha Phaenicophaeus tristis tristis, and Pin-striped Tit Babbler Macronous gularis rubicapilla recorded here are isolated populations lying at the southern most edge of their distribution range in central-west India. Prominent amongst the reptiles 


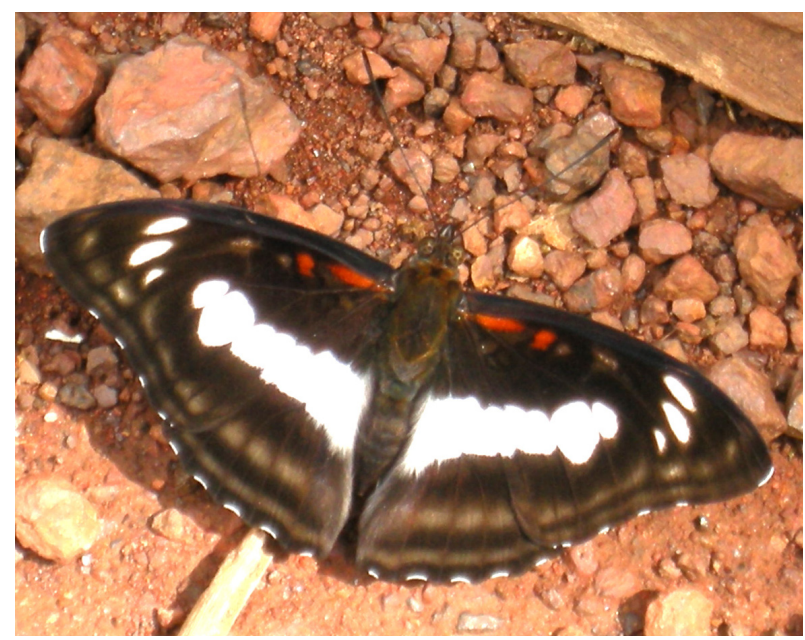

Image 8. Staff Sergeant Athyma selenophora

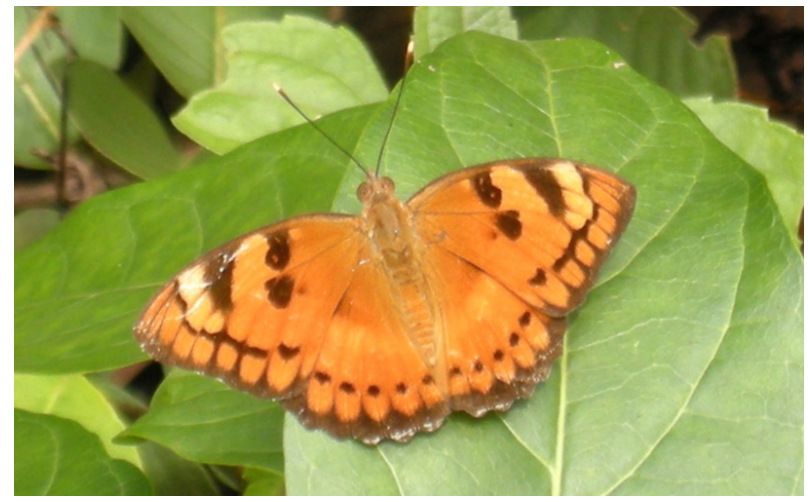

Image 9. Baronet Symphaedra nais

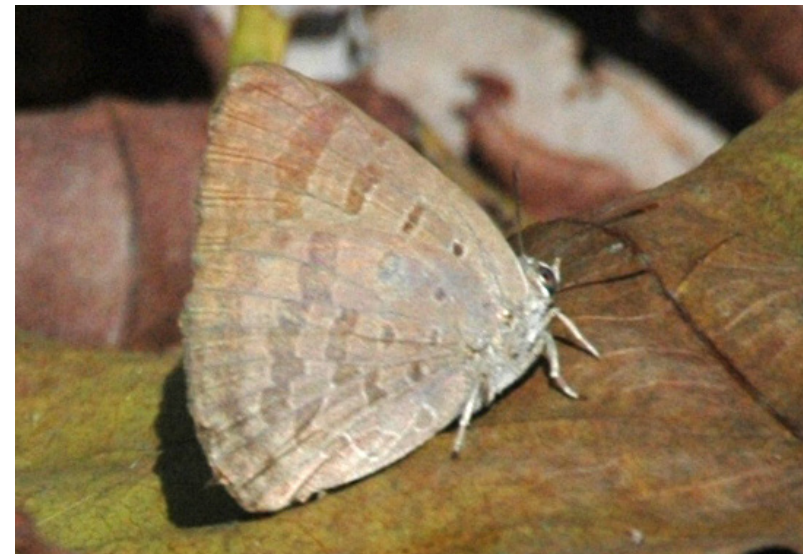

Image 10. Indian Oak Blue Arhopala atrax

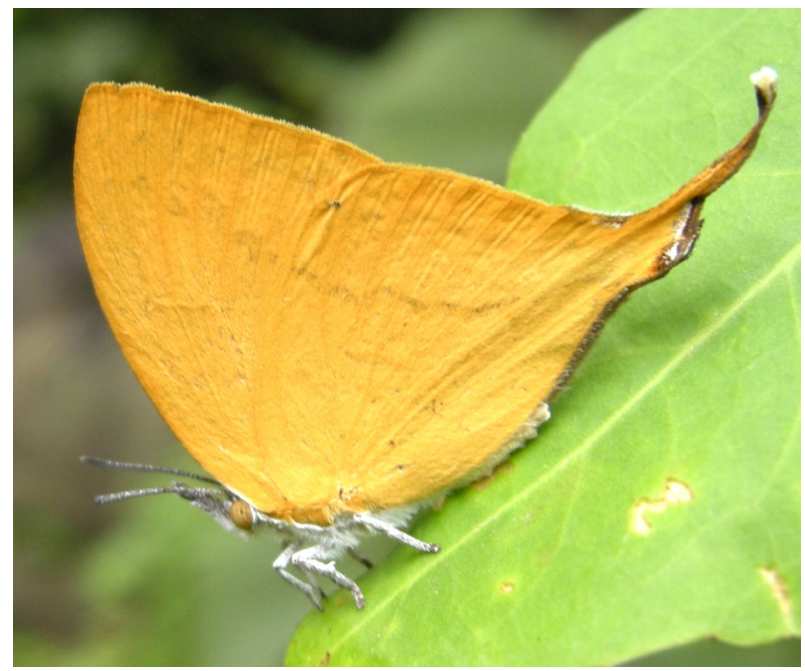

Image 11. Yamfly Loxura atymnus

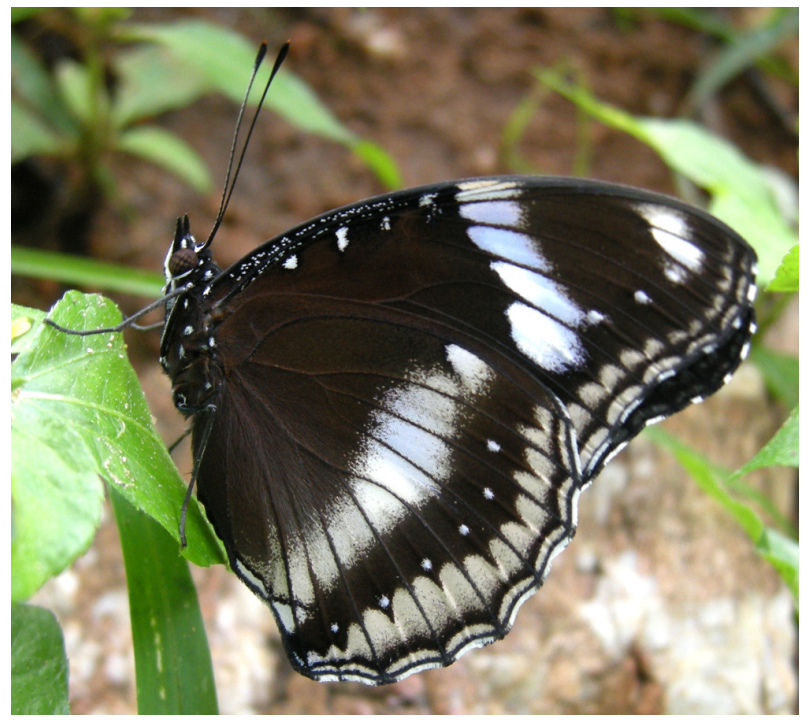

Image 12. Great Eggfly Hypolimnas bolina

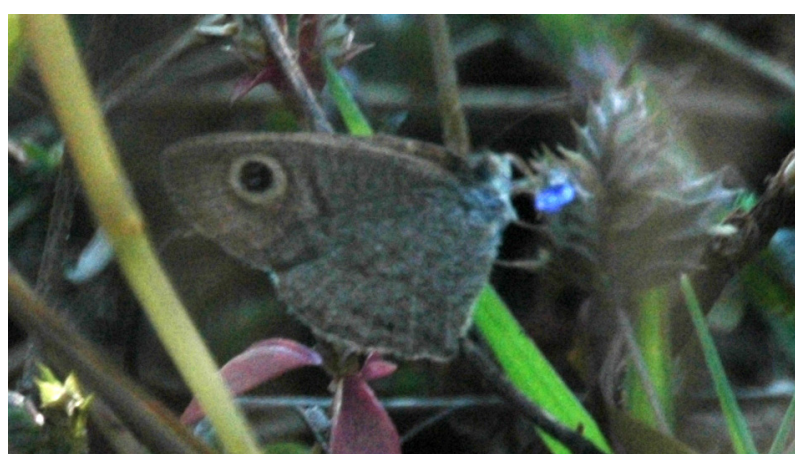

Image 13. Lesser Three Ring Ypthima inica (dry season form - February) 



Image 14. Sal forest habitat in the proposed mining area in Ankua Reserve Forest

was the Indian Chameleon Chamaeleo zeylanicus which is listed in Schedule II of the Indian Wildlife (Protection) Act 1972

The presence of all these species indicates that these forest tracts are rich and unique habitats that hold animal diversity that is typical of 'undisturbed tropical moist deciduous sal forests'. Open cast mining activity including the laying of roads, construction of several civil structures, diversion of water courses, movement of heavy vehicles, labour, firewood collection, etc. would cause disturbance in these habitats (Image 14). These activities can result in habitat fragmentation, population loss and cause local extinctions that would seriously affect the distribution of forest butterflies and other wildlife in the area. Based on the results of this study it is recommended that longterm conservation of these fragmenting sal forest habitats in Saranda Forest Divison is to ensure the biodiversity which can be achieved through 'good mining practices' and/or creating 'biodiversity offsets'.

\section{REFERENCES}

Ackery, P.R. (1984). Systematic and faunistic studies on butterflies, pp.2-91. In: Wright, R.I.V. and P.R. Ackery (eds.). The Biology of Butterflies. Symposium of the Roya Entomological Society of London, Academic Press, No.11.

Anonymous (2006). The Wildlife (Protection) Act 1972. Natraj Publishers, Dehradun, 235pp.

Balmer, O. \& A. Erhardt (2000). Consequences of succession on extensively grazed grassland for central European butterfly communities: Rethinking conservation practices. Conservation Biology 14: 746-757.

Blau, W.S. (1980). The effect of environmental disturbance on a tropical butterfly population. Ecology 61: 1005-1012.

Brown, K.S.(1991). The conservation of insects and their habitats, pp. 350-403. In: Conservation of Neotropical Environments: Insects as Indicators. $15^{\text {th }}$ Symposium of the Royal Entomological Society.

Brunzel, S. \& H. Elligsen (1999). Changes of species set and abundance along a short gradient: The impact of weather conditions on the conservation of butterflies. Beitrage zur Entomologie 49: 447-463.

Champion, H.G. \& S.K. Seth (1968). A Revised Survey of Forest Types of India. Govt. of India Press, Delhi.

Chandra, K., R.M. Mishra, A. Singh \& R.K. Singh (2007). A checklist of butterflies of Madhya Pradesh and Chattisgarh states, India. Zoo's Print Journal 22: 2790-2798.

Choudhury, A., D.K.L. Choudhury, A. Desai, J.W. Duckworth, P.S. Easa, A.J.T. Johnsingh, P. Fernando, S. Hedges, M. Gunawardena, F. Kurt, U. Karanth, A. Lister, V. Menon, H. Riddle, A. Rübel \& E. Wikramanayake (2008). Elephas maximus. In: IUCN 2010. IUCN Red List of Threatened Species. Version 2010.2. <www.iucnredlist.org>. Downloaded on 13 August 2010.

D'Abrera, B. (1982). Butterflies of the Oriental Region - Part I. Papilionidae, Pieridae \& Danaidae. Hill House, Victoria, Australia, 244pp.

D'Abrera, B. (1985). Butterflies of the Oriental Region - Part II. Nymphalidae, Satyridae \& Amathusiidae. Hill House, Victoria, Australia, $534 \mathrm{pp}$.

D'Abrera, B. (1986). Butterflies of the Oriental Region - Part III. Lycaenidae \& Riodinidae. Hill House, Victoria, Australia, 672pp.

Dennis, R.H.L. (1993). Butterflies and Climate Change. University Press, Manchester, xv+302pp.

DFE (2009). Division Wise Composition of Jharkhand Forest 6 Saranda Part I. Chapter-II, A -The Forests. Department of Forests \& Environment, Government of Jharkhand, 31pp. Available online at <http://www.jharkhandforest.com/files/ saranda_terrain.pdf>

Ehrlich, P.R., D.E. Breedlove, P.F. Brussard \& M.A. Sharp (1972). Weather and the regulation of sub-alpine populations. Ecology 53: 243-247.

Ehrlich, P.R. \& P.H. Raven (1964). Butterflies and plants: a study in co-evolution. Evolution 18: 586-608.

Erhardt, A. (1985). Diurnal Lepidoptera: Sensitive indicators of cultivated and abandoned grassland. Journal of Applied Ecology 22: 849-861.

Garshelis, D.L., S. Ratnayeke \& N.P.S. Chauhan (2008). Melursus ursinus. In: IUCN 2010. IUCN Red List of Threatened Species. Version 2010.2. <www.iucnredlist.org>. Downloaded on 13 August 2010.

Haribal, M.(1992) The Butterflies of Sikkim Himalaya and their Natural History. Sikkim Nature Conservation Foundation, Sikkim, 217pp.

Heath, J. (1981). Threatened Rhopalacera (Butterflies) of Europe. Council of Europe, Strasbourg, 157pp. 
Appendix 1. Systematic list of butterflies (Rhopalocera) sampled in Ankua Forest Division, West Singhbhum District, Jharkhand, India (February \& September 2008).

\begin{tabular}{|c|c|c|c|c|}
\hline & Family/Species & February 2008 & September 2008 & $\begin{array}{c}\text { Relative } \\
\text { Abundance (\%) }\end{array}$ \\
\hline A. & \multicolumn{4}{|l|}{ Papilionidae } \\
\hline 1 & Common Banded Peacock, Papilio crino (Fabricius) & + & + & 0.6 \\
\hline 2 & Lime Butterfly, Papilio demoleus (Linnaeus) & + & + & 1.4 \\
\hline 3 & Common Mormon, Papilio polytes (Linnaeus) & - & + & 2.2 \\
\hline 4 & Common Rose, Pachliopta aristolochiae (Fabricius) & - & + & 0.2 \\
\hline 5 & Blue Mormon, Papilio polymnestor (Cramer) & + & + & 2.2 \\
\hline B. & \multicolumn{4}{|l|}{ Pieridae } \\
\hline 6 & Common Emigrant, Catopsila pomona (Fabricius) & + & + & 2.2 \\
\hline 7 & Mottled Emigrant, Catopsilia pyranthe (Linnaeus) & + & + & 0.2 \\
\hline 8 & Common Grass Yellow, Eurema hecabe (Linnaeus) & + & + & 42.4 \\
\hline 9 & Small Grass Yellow, Eurema brigitta (Cramer) & - & + & 1.4 \\
\hline 10 & Common Jezebel, Delias eucharis (Drury) & + & + & 1 \\
\hline 11 & Common Gull, Cepora nerissa (Fabricius) & + & - & 0.4 \\
\hline 12 & Common Wanderer, Pareronia valeria (Cramer) & - & + & 0.2 \\
\hline 13 & Chocolate Albatross, Appias lyncida (Cramer) & - & + & 0.2 \\
\hline 14 & Psyche, Leptosia nina (Fabricius) & - & + & 0.2 \\
\hline C. & \multicolumn{4}{|l|}{ Lycaenidae } \\
\hline 15 & Large Oak Blue, Arhopala amantes (Hewitson) & + & - & 10.8 \\
\hline 16 & Indian Oak Blue, Arhopala atrax (Hewitson) (Image 10) & + & - & 0.2 \\
\hline 17 & Indigo Flash, Rapala varuna (Horsfield) - IWPA1972 & + & - & 0.2 \\
\hline 18 & Common Acacia Blue, Surendra quercetorum (Moore) & - & + & 0.2 \\
\hline 19 & Common Cerulean, Jamides celeno (Cramer) & + & - & 0.2 \\
\hline 20 & Dark Cerulean, Jamides bochus (Stoll) & + & - & 0.2 \\
\hline 21 & Common Hedge Blue, Acytolepis puspa (Horsfield) & + & + & 0.6 \\
\hline 22 & Forget-me-not, Catochrysops strabo (Fabricius) & + & - & 0.6 \\
\hline 23 & Pale Grass Blue, Pseudozizeeria maha (Kollar) & - & + & 0.4 \\
\hline 24 & Zebra Blue, Syntarucus plinius (Fabricius) & + & - & 0.2 \\
\hline 25 & Common Pierrot, Castalius rosimon (Fabricius) & + & + & 0.8 \\
\hline 26 & Angled Pierrot, Caleta caleta (Hewitson) & - & + & 0.4 \\
\hline 27 & Pea Blue, Lampides boeticus (Linnaeus) - IWPA 1972 & + & - & 0.2 \\
\hline 28 & Plains Cupid, Edales pandava (Horsfield) & - & + & 0.2 \\
\hline 29 & Lime Blue, Chilades laius (Stoll) & - & + & 0.2 \\
\hline 30 & Yamfly, Loxura atymnus (Stoll) (Image 11) & - & + & 0.2 \\
\hline 31 & Plum Judy, Abisara echerius (Stoll) & + & + & 1.4 \\
\hline D. & \multicolumn{4}{|l|}{ Nymphalidae } \\
\hline 32 & Tawny Coster, Acraea violae (Fabricius) & + & - & 0.2 \\
\hline 33 & Common Lascar, Pantoporia hordonia (Stoll) & - & + & 0.2 \\
\hline 34 & Common Sailer, Neptis hylas (Linnaeus) & + & + & 3.8 \\
\hline
\end{tabular}




\begin{tabular}{|c|c|c|c|c|}
\hline & Family/Species & February 2008 & September 2008 & $\begin{array}{c}\text { Relative } \\
\text { Abundance (\%) }\end{array}$ \\
\hline 35 & Clear Sailer, Neptis clinia (Moore) & + & - & 0.2 \\
\hline 36 & Common Sergeant, Athyma perius (Linnaeus) & + & + & 0.6 \\
\hline 37 & Colour Sergeant, Athyma nefte (Cramer) & - & + & 0.6 \\
\hline 38 & Staff Sergeant, Athyma selenophora (Kollar) & + & + & 1 \\
\hline 39 & Blue Pansy, Junonia orithya (Linnaeus) & + & + & 0.8 \\
\hline 40 & Chocolate Pansy,Precis iphita (Cramer) & + & + & 3.6 \\
\hline 41 & Peacock Pansy, Precis almana (Linnaeus) & - & + & 0.4 \\
\hline 42 & Common Map, Cyrestis thyodamas (Boisduval) & + & - & 0.4 \\
\hline 43 & Leopard Lacewing, Cethosia cyane (Drury)* & + & - & 0.4 \\
\hline 44 & Common Leopard, Phalanta phalantha (Drury) & - & + & 0.8 \\
\hline 45 & Common Baron, Euthalia aconthea (Cramer) & - & + & 0.2 \\
\hline 46 & Rajah, Charaxes sp. & - & + & 0.2 \\
\hline 47 & Gaudy Baron, Euthalia Iubentina (Cramer) - IWPA1972 & - & + & 0.4 \\
\hline 48 & Lemon Pansy, Precis lemonias (Linnaeus) & + & + & 1 \\
\hline 49 & Grey Count, Tanaecia lepidea (Butler) & + & + & 2.6 \\
\hline 50 & Orange Oak Leaf, Kallima inachus (Boisduval) & + & + & 0.4 \\
\hline 51 & Great Eggfly, Hypolimnas bolina (Linnaeus) (Image 12) & - & + & 0.4 \\
\hline 52 & Common Castor, Ariadne merione (Cramer) & - & + & 0.2 \\
\hline 53 & Baronet, Symphaedra nais (Forster) & - & + & 1.6 \\
\hline 54 & Commander, Moduza procris (Cramer ) & - & + & 0.4 \\
\hline 55 & Common Evening Brown, Melanitis leda (Linnaeus) & + & + & 0.4 \\
\hline 56 & Dark-branded Bush Brown, Mycalesis mineus (Linnaeus) & - & + & 0.4 \\
\hline 57 & Common Bush Brown, Mycalesis perseus (Fabricius) & - & + & 0.2 \\
\hline 58 & Lesser Three Ring, Ypthima inica (Hewitson) (Image 13) & + & + & 0.4 \\
\hline 59 & Common Four Ring, Ypthima hübneri (Kirby) & + & + & 0.4 \\
\hline 60 & Common Palmfly, Elymnias hypermnestra (Linnaeus) & - & + & 0.2 \\
\hline 61 & Common Indian Crow, Euploea core (Cramer) & + & + & 0.2 \\
\hline 62 & Glassy Tiger, Parantica aglea (Cramer) & + & - & 1.2 \\
\hline 63 & Blue Tiger, Tirumula limniace (Cramer) & + & - & 0.2 \\
\hline 64 & Striped Tiger, Danaus genutia (Cramer) & + & + & 0.2 \\
\hline $\mathbf{E}$ & Hesperidae & & & \\
\hline 65 & Grass Demon, Udaspes folus (Cramer) & - & + & 0.6 \\
\hline 66 & Restricted Demon, Notocrypta curvifascia (C.\&R..Felder)* & - & + & 0.2 \\
\hline 67 & Common Small Flat, Sarangesa dasahara (Moore) & + & + & 1 \\
\hline 68 & Water Snow Flat, Tagiades litigiosa (Möschler) & - & + & 0.4 \\
\hline 69 & Conjoined Swift, Pelopidas conjuncta (Herrich-Schäffer) & - & + & 0.4 \\
\hline 70 & Straight Swift, Parnara guttatus (Bremer \& Grey) & - & + & 0.6 \\
\hline \multirow[t]{2}{*}{71} & Indian Palm Bob, Suastus gremius (Fabricius) & - & + & 0.8 \\
\hline & Total (number of species occurring in both the seasons $=24$ ) & 39 & 56 & \\
\hline
\end{tabular}

IWPA1972 - Species listed in Indian Wildlife Protection Act 1972, Schedule II, Part I; * - New records for Jharkhand State 
Kocher, S.D. \& E.H. Willaims (2000). The diversity and abundance of North American butterflies vary with habitat disturbance and geography. Journal of Biogeography 27: 785-794.

Krebs, C. (1989) Ecological Methodology. HarperCollins, New York, 654pp.

Kremen, C. (1992). Assessing the indicator properties of species assemblages for natural area monitoring. Ecological Applications 2: 203-217.

Kunte, K. (1997). Seasonal patterns in butterfly abundance and species diversity in four tropical habitats in northern Western Ghats. Journal of Biosciences 22: 593-603.

Kunte, K., A. Joglekar, G. Utkarsh \& P. Padmanabhan (1999). Patterns of butterfly, bird and tree diversity in the Western Ghats. Current Science 77: 577-586.

Kunte, K. (2000). Butterflies of Peninsular India. University Press, Hyderabad, India, 254pp.

Morrison-Godfrey, P.W. (1950). Butterflies of south Bihar. Journal of Bombay Natural History Society 47: 644-651.

Magurran, A.F. (1988). Ecological Diversity and Its Measurements. University Press, Cambridge, 192pp.

Odum, E.P. (1997). Ecology: A Bridge between Science and Society. Sinauer Associated Inc. Sunderland, Massachusetts, USA, 330pp

Pielou, E.C. (1969). An Introduction to Mathematical Ecology. John Wiley, New York, 286pp.

Rajamani, N., S. Molur \& P.O. Nameer (2009). Ratufa indica. In: IUCN 2010. IUCN Red List of Threatened Species. Version 2010.2. <www.iucnredlist.org>. Downloaded on 13 August 2010.

Rosenberg, D.M., H.V. Danks. \& D.M. Lehmkuhl (1986) Importance of insects in environmental impact assessment. Environmental Management 10: 773-783.

Shannon, C.E. (1948). A mathematical theory of communication. Bell System Technical Journal 27: 379-423 \& 623-656. http:// $\mathrm{cm}$.bell-labs.cpm/cm/ms/what/shannonday/paper.html
Sinha, J.N. (1962). Fourth Revised Working Plan for the Reserved and Protected Forests of Saranda Division, Bihar 1956-57 to 1975-76. Superintendent, Secretariat Press, Bihar (Patna), 257pp.

Sørensen, T.A. (1948). A method of establishing groups of equal amplitude in plant sociology based on similarity of species content, and its application to analyses of the vegetation on Danish commons. Kongelige Danske Videnskabernes Selskabs Biologiske Skrifter 5: 1-34.

Spitzer, K., J. Jaros, J. Havelka, \& J. Laps (1997). Effect of small- scale disturbance on butterfly communities of an Indochina montane rainforest. Biological Conservation 80: 9-15.

Verma, S.K. (2009). Species composition and seasonal variation of butterflies in Dalma Wildlife Sanctuary, Jharkhand, India. Journal of Threatened Taxa 1(5): 295-297.

Talbot, G. (1939). The Fauna of British India including Ceylon and Burma. Butterflies. $2^{\text {nd }}$ edition.Vol. I . Taylor \& Francis, London. 600pp.

Talbot, G. (1947) The Fauna of British India including Ceylon and Burma. Butterflies. $2^{\text {nd }}$ edition Vol II. Taylor \& Francis, London, 506pp.

ten Kate, K., J. Bishop, \& R. Bayon (2004). Biodiversity Offsets: Views, Experience, and the Business Case. IUCN Gland, Switzerland and Cambridge, UK and Insight Investment, London, UK, 95pp. http://www.iucn.org/search. cfm? UNewsID=471

Watt W.B., F.S. Chew, L.R.G. Snyder, A.G. Watt \& D.E. Rothschild (1968). Population structure of pierid butterflies, I. Numbers and movements of some montane Colias species. Oecologia, Berl. 27: 1-2.

Wynter-Blyth, M.A. (1957). Butterflies of the Indian Region. Bombay Natural History Society, Bombay, 523pp. 